\title{
Synthesis, characterization and anticancer activity of novel hydrazide-hydrazones derived from ethyl paraben
}

\author{
M. İhsan HAN 1 * (D), Pınar ATALAY 2 (D), Nalan İMAMOĞLU 2 (D), Ş. Güniz KÜÇÜKGÜZEL 3 (D) \\ 1 Department of Pharmaceutical Chemistry, Faculty of Pharmacy, Erciyes University, Kayseri, Turkey \\ 2 Department of Basic Sciences, Faculty of Pharmacy, Erciyes University, Kayseri, Turkey \\ 3 Department of Pharmaceutical Chemistry, Faculty of Pharmacy, Marmara University, İstanbul, Turkey \\ * Corresponding Author. E-mail: hanihsan@gmail.com (M.İ.H.); Tel: +90 35220766 66/2 8034.
}

Received: 31 January 2020 / Revised: 26 February 2020 / Accepted: 30 March 2020

\begin{abstract}
Parabens, which are hydroxybenzoic acid esters, are particularly used as protective against mold and fungus. Ethyl paraben is a compound open to modification for the synthesis of new molecules due to the ester group in its structure. In this study, ethyl paraben was used as a starting material. A new series of novel hydrazide-hydrazones from derived ethyl paraben were synthesized and characterized by spectroscopic techniques such as NMR, FT-IR besides elemental analysis. In order to determine the anticancer activity of the aimed ethyl paraben hydrazidehydrazones we evaluated their cytotoxic activity on liver cancer cell line liver hepatocellular carcinoma (HepG2). Herein we described several 4-hydroxy-N'-[substituted methylidene] benzohydrazides (3a-j) as anticancer agents. We designed, synthesized and characterized the series of novel hydrazide-hydrazones from ethyl paraben. All of the compounds evaluated for anticancer activity by using MTT assay for 24 and $48 \mathrm{~h}$. mRNA transcription levels of Bax, $\mathrm{Bcl}-2$ and caspase- 3 genes were determined by realtime polymerase chain reaction (qRT-PCR) analysis. Compounds $3 \mathrm{i}$ and $3 \mathrm{j}$ showed anticancer activity with 42.4 and $37.4 \mu \mathrm{M} \mathrm{IC}_{50}$ values, respectively. Doxorubicin was used as a positive sensitivity reference standard. qRTPCR analysis approved that there was a timedependent rise in the expression levels of Bax, Bcl-2 and Caspase 3 on apoptosis. The activities of the synthesized compounds changed depending on the dose and time of treatment and some of the molecules started to show activity within 48 hours.
\end{abstract}

KEYWORDS: Ethyl paraben; hydrazide-hydrazone; anticancer acitivity; MTT assay; qRT-PCR; HepG2.

\section{INTRODUCTION}

Cancer is a disease characterized by the growth of abnormal cells caused by the gene mutation of normal cells and uncontrolled cell proliferation. Recently, chemotherapeutic drugs have been used for the cancer cure. The side-effects, toxicity, and the drug resistance of these drugs limit their use in the cure. Parabens are considered to be ideal preservatives with a wide spectrum of antibacterial effects, the safety of use (no irritation, low toxicity), chemical stability over a wide $\mathrm{pH}$ range and high solubility in the water phase. Parabens are esters of p-hydroxybenzoic acid, with alkyl substituents ranging from methyl to butyl or benzyl groups [1]. Parabens are synthesized by esterification of p-hydroxybenzoic acid with suitable alcohol in the presence of a catalyst like concentrated $\mathrm{H}_{2} \mathrm{SO}_{4}$ [2]. The antimicrobial effects of parabens increase with the elongation of the chains of ester groups, but with the rise in the alkyl chain length, the resistance of aqueous solutions of parabens to hydrolysis improves generally. The plenty of property parabens to usage as protecting agents have contributed to their important popularity. Parabens were first used as preservatives in drugs in the mid-1920s. Recently, they have utilized preservatives, mainly in cosmetics and pharmaceuticals [3]. The inhibitory activity of parabens on microbial growth is known. Parabens are much more susceptible to spore growth cells than vegetative growth of bacteria or fungi. The activity of parabens on low concentration fungi was found [4]. Parabens were considered innocent and hence they have been used as protectives widely, in personal care products for a long time. An alive discussion on paraben safety is ongoing over the last two decades. The basic fear increases from their endocrine-disrupting potency [5]. When the fertility levels of the pairs were examined about the urinary concentrations of parabens, it was observed that the fertility level decreased by $33 \%$ due to the urinary concentration of ethyl paraben before mating in females compared to males [6]. Ethyl 4-hydroxybenzoate, also known as ethyl paraben, is formed by the reaction of the carboxy group of 4-hydroxybenzoic acid with ethanol. Ethyl paraben is a preventive compound that has used for

How to cite this article: Han Mi, Atalay P, İmamoğlu N, Küçükgüzel ŞG. Synthesis, characterization and anticancer activity of novel hydrazidehydrazones derived from ethyl paraben. J Res Pharm. 2020; 24(3): 341-349. 
antimicrobial and stability effects in drugs, cosmetics or foods. Due to its harmful effects, its use in many areas has been restricted in recent years. In this study, ethyl paraben was used as a starting compound because of the containing ester functional group. The phenol group of the molecule is thought to contribute to the anticancer activity. Hydrazide-hydrazones are having an azomethine $(-\mathrm{NHN}=\mathrm{CH}-)$ proton and form a significant class of compounds to novel drug designing. The activity of hydrazide-hydrazones is known to be associated with the active pharmacophoric group. As a result of this, many researchers have synthesized new hydrazide-hydrazones as aimed structures and evaluated their various activities [7-13]. It has been noticed that hydrazide-hydrazones have anticancer activity in previous studies [14-23]. Thus, we focused our interest on the hydrazide-hydrazone structure. A novel series of hydrazide-hydrazone derivatives were synthesized from ethyl paraben and evaluated for their anticancer activity against hepatocellular cancer cell line HepG2 in vitro.

\section{RESULTS AND DISCUSSION}

Ethyl paraben, ethyl-4-hydroxybenzoate, was chosen as a starting compound in this study. 4hydroxybenzohydrazide was prepared according to the previously reported methods [24]. The novel hydrazide-hydrazones from derived ethyl paraben (3a-j) were synthesized in this study. The synthesis of these compounds is shown in Figure 1.

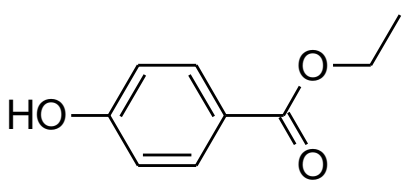

(1)

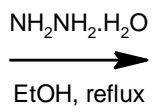

$\mathrm{EtOH}$, reflux<smiles>NNC(=O)c1ccc(O)cc1</smiles>

(2)

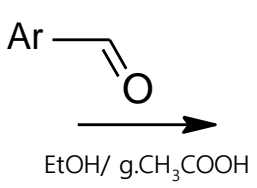

$\overbrace{\mathrm{O}}^{\mathrm{NO}} \mathrm{N}_{\mathrm{Ar}}$

(3a-j)

Figure 1. Synthetic route to hydrazide-hydrazones from ethyl paraben (3a-j).

Ethyl paraben and hydrazine-hydrate $80 \%$ were refluxed in ethanol to prepare 4hydroxybenzohydrazide (2). The ethyl paraben hydrazide-hydrazones were synthesized from aryl aldehydes with compound 2 in the ethanolic medium in a few drops of glacial acetic acid. The purity of the compounds was confirmed with thin layer chromatography (TLC), high-pressure liquid chromatography (HPLC), and elemental analysis. The structures of compounds (3a-j) were confirmed using FT-IR, ${ }^{1} \mathrm{H}-\mathrm{NMR}$. The FT-IR spectra showed that hydrazide $C=O$ stretching bands were shifted from $1645 \mathrm{~cm}^{-1}$ to $1687 \mathrm{~cm}^{-1}$. In compounds, $\mathrm{O}-\mathrm{H}$ bands were screened at 3201-3296 $\mathrm{cm}^{-1}$ and N-H bands were screened at 3041-3088 $\mathrm{cm}^{-1}$. Also, the C=N stretching bands were detected between $1602-1622 \mathrm{~cm}^{-1}$; altogether proved the characteristic hydrazone $\mathrm{C}=\mathrm{N}$ stretching bands. Phenol C-O and halogen C-F stretching data between 1257-1236 and 1118-1105 $\mathrm{cm}^{-1}$, respectively. The FT-IR spectra results of new ethyl paraben hydrazide-hydrazones supported the process of condensation. The asset of the hydrazone $\mathrm{C}=\mathrm{N}$ stretching bands proved the hydrazide-hydrazones synthesis. ${ }^{1} \mathrm{H}-\mathrm{NMR}$ spectra results of azomethine $=\mathrm{C} \underline{\mathrm{H}}$, phenol $-\mathrm{O} \underline{\mathrm{H}}$ and hydrazone $-\mathrm{N} \underline{\mathrm{H}}-$ protons $(3 \mathrm{a}-\mathrm{j})$ confirmed the formation of hydrazide-hydrazones. ${ }^{1} \mathrm{H}-\mathrm{NMR}$ spectral data of compounds $3 \mathrm{a}-\mathrm{j}$ demonstrated supporting proof to detect their structures. The singlet signals belonging to azomethine proton in all compounds were detected at $8.38-8.86 \mathrm{ppm}$. The $-\mathrm{OH}$ proton in all compounds were detected at $10.14-10.81 \mathrm{ppm}$. The $-\mathrm{NH}-$ proton of compounds 3a-j were detected at the range of 11.47-12.07 ppm. The azomethine proton was observed in the spectrum at the range of 8.0-9.0 ppm. In this study, azomethine protons of the synthesized molecules were observed in this range. The presence of the azomethine proton is proof of the synthesis.

The various activities of ethyl paraben, the synthesis starting compound, have been reported. On the light of these, we targeted to detect the anticancer activity of ethyl paraben hydrazide-hydrazones (3a-j). The 
sensitivity of the liver cancer cell lines towards the compounds was evaluated from the MTT method. The anticancer activity of the compounds was evaluated against the HepG2 liver cancer cell line. Doxorubicin was used as the positive control reference standard for the cell line. Compounds $3 a-j$ were found with $\mathrm{IC}_{50}$ values of 37.4-400 $\mu \mathrm{M}$ according to MTT assay for 24 and $48 \mathrm{~h}$. The results of the anticancer activity of synthesized compounds 3a-j are given in Table 1.

Table 1. $\mathrm{IC}_{50}$ values of compounds $\mathbf{3 a - j}$.

\begin{tabular}{lll}
\hline & \multicolumn{2}{l}{ IC $_{50}$ values $(\boldsymbol{\mu M})$} \\
\hline Compound & $\mathbf{2 4} \mathbf{~ h}$ & $\mathbf{4 8 ~ h}$ \\
\hline $\mathbf{3 a}$ & $>400$ & 395 \\
$\mathbf{3 b}$ & 116.1 & 70.7 \\
$\mathbf{3 c}$ & 126.2 & 70.7 \\
$\mathbf{3 d}$ & 235.3 & 75.0 \\
$\mathbf{3 e}$ & $>400$ & $>400$ \\
$\mathbf{3 f}$ & $>400$ & 288 \\
$\mathbf{3 g}$ & $>400$ & 64.9 \\
$\mathbf{3 h}$ & 359 & 242 \\
$\mathbf{3 i}$ & $\mathbf{6 1 . 5}$ & $\mathbf{3 7 . 4}$ \\
$\mathbf{3 j}$ & $\mathbf{6 3 . 6}$ & $\mathbf{4 2 . 4}$ \\
Doxorubicin & 1.7 & 0.8 \\
\hline
\end{tabular}

HepG2 cells were exposed to $3 \mathrm{i}$ and $3 \mathrm{j}(25-50 \mu \mathrm{M})$, and we applied messenger RNA (mRNA) expression analysis of the Bax, Bcl-2, and Caspase 3. In the $3 \mathrm{i}$ and $3 \mathrm{j}$ treated HepG2 cells, realtime polymerase chain reaction (RTPCR) analysis showed that there was a time-dependent rise in the expression levels of Bax, Bcl-2, and Caspase 3, compared with the control and Doxorubicin. In this study, we researched the impacts of compounds $3 \mathrm{i}$ and $3 \mathrm{j}$ on the mitochondrial membrane potential Bax and Bcl-2 as mitochondrial apoptotic markers and caspase- 3 activation as a marker to the point of convergence of the intrinsic and extrinsic apoptotic ways in the HepG2 cell line. Our data demonstrated that $48-\mathrm{h}$ treatment with compounds $3 \mathrm{i}$ and $3 \mathrm{j}$ directly up-regulated Bax and Bcl-2 expression and induced caspase-3 dependent apoptosis in the HepG2 cell line. Normally the cells going to apoptosis, the Bax level increases while the Bcl-2 ratio decreases. However, in this study, although the level of Bcl-2 increased, cells with increased caspase- 3 activity going to apoptosis in $3 \mathrm{i}$ and 3j-treated HepG2 cells [25]. All these results demonstrated that treatment with $3 \mathrm{i}$ and $3 \mathrm{j}$ caused a significant increase in apoptotic markers (Figure 2A-D). The values found as a result of statistical studies were found significant in terms of statistical data. The values are shown on the graph * $P \backslash 0.05$ versus respective control (0 min), ANOVA followed by post-test.

For the prediction of ADME properties of the molecules, a computational work was used by definition of topological polar surface area (TPSA), lipophilicity, absorption (ABS\%) and simple molecular descriptors used by Lipinski in formulating his "rule of five". Calculations were performed using Molinspiration on-line feature calculation toolkit [26] (Table 2). Percentage of absorption (ABS\%) was predicted using the equation: $\mathrm{ABS} \%=109-(0.345 \times \mathrm{TPSA})[21,22]$.

\section{CONCLUSION}

In search of new molecules with anticancer features, we have designed and synthesized a series of novel ethyl paraben hydrazide-hydrazones. It is established from this research that hydrazide-hydrazone functionality rises the anticancer activity of the many compounds. In vitro, these compounds were evaluated against liver cancer cell line HepG2. These compounds ( $3 \mathrm{i}$ and $3 \mathrm{j}$ ) possessed anticancer activity against the cell line HepG2 with 37.4 and $42.4 \mu \mathrm{M}$. Doxorubicin was used as a positive sensitivity reference standard for cell lines. 


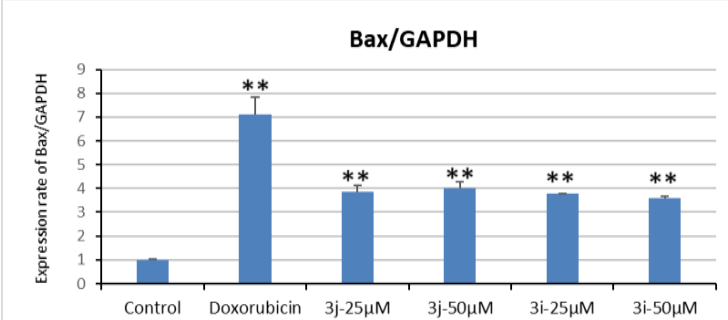

A)

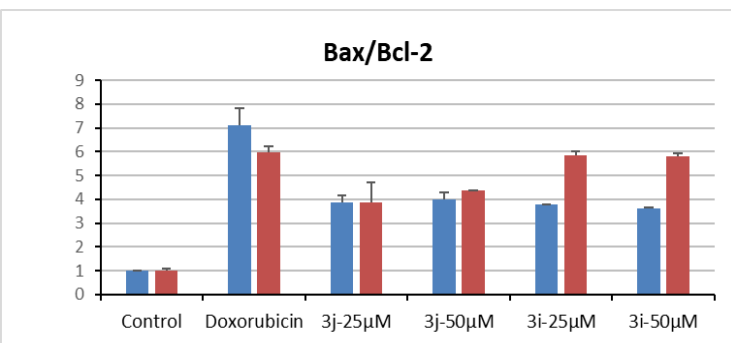

C)

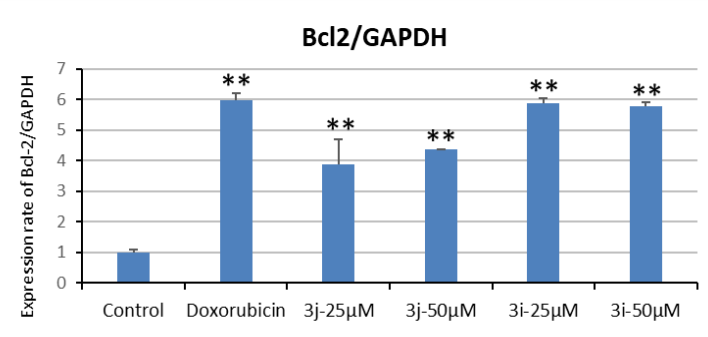

B)

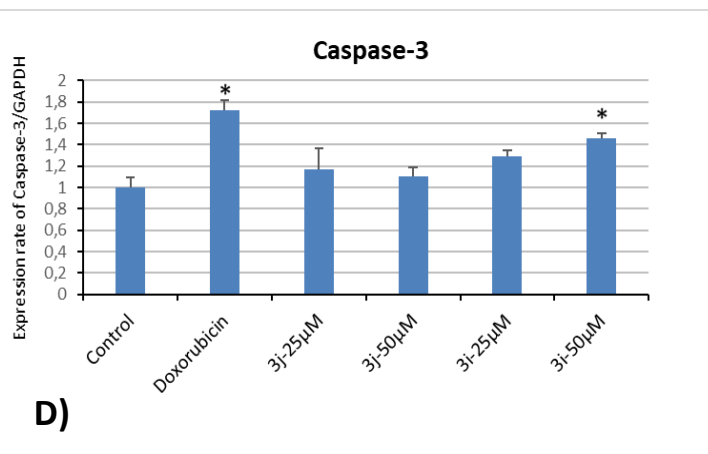

Figure 2. A) Expression rate of Bax/GAPDH B) Expression rate of Bcl-2/GAPDH C) expression levels of Bcl-2 and Bax protein and ratio of Bax/Bcl-2 expression on HepG2 cells. D) Effects of compounds $3 \mathrm{i}$ and $3 \mathrm{j}$ on caspase-3 activity on HepG2 cells. ${ }^{*} \mathrm{p}<0.05$ and ${ }^{* *} \mathrm{p}<0.01$ versus $\mathrm{C}$ (Control).

Table 2. Estimated ADME, Lipinski parameters and molecular features of the synthesized compounds 3a-j.

\begin{tabular}{lcccccccc}
\hline Compound & ABS\% & TPSA & $\begin{array}{c}\text { n- } \\
\text { ROTB }\end{array}$ & $\begin{array}{c}\text { n-ON } \\
\text { acceptors }\end{array}$ & $\begin{array}{c}\text { n-OHNH } \\
\text { donors }\end{array}$ & $\begin{array}{c}\text { Mi } \\
\text { LogP }\end{array}$ & $\begin{array}{c}\text { Formula } \\
\text { weight }\end{array}$ & $\begin{array}{c}\text { n- } \\
\text { Violations }\end{array}$ \\
\hline 3a & 87.71 & 61.69 & 4 & 4 & 2 & 3.61 & 326.25 & 0 \\
3b & 84.53 & 70.92 & 5 & 5 & 2 & 3.54 & 324.26 & 0 \\
3c & 84.53 & 70.92 & 5 & 5 & 2 & 3.56 & 324.26 & 0 \\
3d & 84.53 & 70.92 & 5 & 5 & 2 & 3.59 & 324.26 & 0 \\
3e & 84.53 & 70.92 & 4 & 5 & 2 & 2.77 & 288.28 & 0 \\
3f & 84.53 & 70.92 & 4 & 5 & 2 & 3.26 & 304.73 & 0 \\
3g & 87.71 & 61.69 & 5 & 4 & 2 & 4.34 & 376.26 & 0 \\
3h & 81.34 & 80.16 & 5 & 6 & 2 & 2.64 & 300.31 & 0 \\
3i & 87.71 & 61.69 & 4 & 4 & 2 & 4.24 & 322.39 & 0 \\
3j & 84.53 & 70.92 & 5 & 5 & 2 & 4.46 & 350.35 & 0 \\
Ethyl & 92.94 & 46.53 & 3 & 3 & 1 & 2.00 & 166.18 & 0 \\
paraben & & & & & & & &
\end{tabular}

\section{MATERIALS AND METHODS}

\subsection{Chemistry}

All aldehydes were purchased from Sigma Aldrich. All other chemicals and solvents were purchased from Merck. Melting points were taken on Schmelzpunktbestimmer 9300 SMP II apparatus and are uncorrected. Synthesis of these compounds was carried out in the Memmert WNB14 instrument and Heidolph MR Plug Radley. Merck silica gel 60 F254 plates were used for analytical TLC. The purity of the compounds was controlled on TLC plates precoated with silica gel $\mathrm{G}$ in a solvent system comprising of petroleum ether: ethyl acetate $\left(40: 60, \mathrm{v} / \mathrm{v}, \mathrm{t}: 25^{\circ} \mathrm{C}\right)$ mixture as eluent. The spots were located under UV light $(254 \mathrm{~nm})$. HPLC data were performed on Agilent Technologies 1200 series, G1379B vacuum degasser, G1329A autosampler G1315D DAD detector. The separation was performed at ambient temperature using a reverse-phase ACE C18 column $(150 \times 4.6 \mathrm{~mm}, 5 \mu \mathrm{m}$, HiChroma, UK). All experiments were performed in isocratic mode. Acetonitrile: bidistillee water system was used as a gradient system: 60:40 the flow rate was $1.2 \mathrm{~mL} / \mathrm{min}$ with monitoring 
at $260 \mathrm{~nm}$ (M1). Elemental analyses were performed on VarioMICRO V1.5.7. instrument. FT-IR spectra were run on Schimadzu FTIR-8400S spectrophotometer. ${ }^{1} \mathrm{H}-\mathrm{NMR}$ spectra were obtained on a BRUKER AVANCEDPX 300 instrument (Elemental analysis and ${ }^{1} \mathrm{H}-\mathrm{NMR}$ spectrum exist in İnönü University Scientific and Technological Research Center).

\subsubsection{Preparation of 4-hydroxybenzohydrazide (2)}

In the first step, 4-hydroxybenzohydrazide (2) synthesis was carried out. $0.01 \mathrm{Mol}$ of ethyl paraben was dissolved in $50 \mathrm{ml}$ of ethanol. Hydrazine-hydrate $(20 \mathrm{~mL})$ was added to the solution and refluxed for 8 hours in a water bath. The reaction was finished by TLC monitoring. To obtain the solid product, distilled water was added to the reaction medium and kept in the fridge for 1 night. The precipitated solid was filtered, washed with water and dried. The product was recrystallized from ethanol.

\subsubsection{General procedure for the synthesis of 4-hydroxy-N'-[substitutedmethylidene] benzohydrazides (3a-j).}

Compound $2(0.01 \mathrm{~mol})$ was dissolved in ethanol $(20 \mathrm{ml})$ and an equimolar amount of substituted aromatic aldehyde were added to the reaction mixtures and refluxed for 8 hours. The product was precipitated, filtered, and washed with distilled water. The compounds were recrystallized from ethanol.

$N^{\prime}$-\{[4-fluoro-3-(trifluoromethyl)phenyl]methylidene\}-4-hydroxybenzohydrazide (3a)

White solid. Yield 60\%; m.p. 301-302 ${ }^{\circ} \mathrm{C}$; MW: 326.24 g/mol; Rf: 0.85; Rt value: $2.240 \mathrm{~min}$ (M1). FT-IR v max. (cm-1): 3267 (O-H), 3088 (N-H), 2978 (Arom C-H), 2922 (Aliph. C-H), 1645 ( C=O), 1606 (C=N), 1575, 1548, 1506, 1491 (arom. C=C, N-H, C-N), 1263 (C-O), 1111 (C-F). ${ }^{1} \mathrm{H}-\mathrm{NMR}$ (300 MHz, DMSO-d 6 /TMS) $\delta_{\mathrm{H}}$ ppm: 6.86$8.28(\mathrm{~m}, 7 \mathrm{H}, \mathrm{Ar}-\mathrm{H}), 8.77(\mathrm{~s}, 1 \mathrm{H},-\mathrm{N}=\mathrm{CH}), 10.20(\mathrm{~s}, 1 \mathrm{H}, \mathrm{Ar}-\mathrm{OH}), 11.98(\mathrm{~s}, 1 \mathrm{H}, \mathrm{CO}-\mathrm{NH})$. Anal. Cald. $\mathrm{C}_{15} \mathrm{H}_{10} \mathrm{~F}_{4} \mathrm{~N}_{2} \mathrm{O}_{2}$. Calculated/Found (\%): C: 55.22/54.56 H: 3.09/3.04 N: 8.59/8.72.

\section{$N^{\prime}-\{[2$-(trifluoromethoxy)phenyl]methylidene\}-4-hydroxybenzohydrazide (3b)}

White solid. Yield 70\%; m.p. 199-201 ${ }^{\circ} \mathrm{C}$; MW: 324.25 g/mol; Rf: 0.60; Rt value: 2.150 min (M1). FT-IR v max. (cm-1): $3248(\mathrm{O}-\mathrm{H}), 3055$ (N-H), 3007 (Arom C-H), 2933 (Aliph. C-H), 1681 ( C=O), 1606 (C=N), 1581, 1541, 1510, 1485 (arom. C=C, N-H, C-N), 1257 (C-O), 1118 (C-F). ${ }^{1} \mathrm{H}-\mathrm{NMR}$ (300 MHz, DMSO-d 6 /TMS) $\delta_{\text {H }}$ ppm: 6.85$8.08(\mathrm{~m}, 8 \mathrm{H}, \mathrm{Ar}-\mathrm{H}), 8.71(\mathrm{~s}, 1 \mathrm{H},-\mathrm{N}=\mathrm{CH}), 10.18(\mathrm{~s}, 1 \mathrm{H}, \mathrm{Ar}-\mathrm{OH}), 11.81(\mathrm{~s}, 1 \mathrm{H}, \mathrm{CO}-\mathrm{NH})$. Anal. Cald. $\mathrm{C}_{15} \mathrm{H}_{11} \mathrm{~F}_{3} \mathrm{~N}_{2} \mathrm{O}_{3}$. Calculated/Found (\%): C: 55.56/54.95 H: 3.42/3.45 N: 8.64/8.34.

$N^{\prime}-\{[3$-(trifluoromethoxy)phenyl]methylidene\}-4-hydroxybenzohydrazide (3c)

White solid. Yield 73\%; m.p. 198-199 ${ }^{\circ} \mathrm{C}$; MW: 347.25 g/mol; Rf: 0.66; Rt value: 2.141 min (M1). FT-IR v max. (cm-1): $3211(\mathrm{O}-\mathrm{H}), 3072(\mathrm{~N}-\mathrm{H}), 2970$ (Arom C-H), 2924 (Aliph. C-H), 1687 ( C=O), 1606 (C=N), 1581, 1558, 1508, 1485 (arom. C=C, N-H, C-N), 1238 (C-O), 1112 (C-F). ${ }^{1} \mathrm{H}-\mathrm{NMR}$ (300 MHz, DMSO-d 6 /TMS) $\delta_{\mathrm{H}}$ ppm: 6.85$7.82(\mathrm{~m}, 8 \mathrm{H}, \mathrm{Ar}-\mathrm{H}), 8.45(\mathrm{~s}, 1 \mathrm{H},-\mathrm{N}=\mathrm{CH}), 10.18(\mathrm{~s}, 1 \mathrm{H}, \mathrm{Ar}-\mathrm{OH}), 11.81(\mathrm{~s}, 1 \mathrm{H}, \mathrm{CO}-\mathrm{NH})$. Anal. Cald. $\mathrm{C}_{15} \mathrm{H}_{11} \mathrm{~F}_{3} \mathrm{~N}_{2} \mathrm{O}_{3}$. $1 / 2 \mathrm{C}_{2} \mathrm{H}_{5} \mathrm{OH}$. Calculated/Found (\%): C: 55.33/55.37 H: 4.06/4.13 N: 8.07/7.65.

$N^{\prime}$-\{[4-(trifluoromethoxy)phenyl]methylidene\}-4-hydroxybenzohydrazide (3d)

White solid. Yield 66\%; m.p. $211^{\circ} \mathrm{C}$; MW: 324.25 g/mol; Rf: 0.71; Rt value: 2.138 min (M1). FT-IR v max. (cm-1): 3223 (O-H), 3041 (N-H), 2941 (Arom C-H), 2887 (Aliph. C-H), 1681 (C=O), 1602 (C=N), 1581, 1548, 1504, 1485 (arom. C=C, N-H, C-N), 1242 (C-O), 1105 (C-F). ${ }^{1} \mathrm{H}-\mathrm{NMR}\left(300 \mathrm{MHz}, \mathrm{DMSO}-\mathrm{d}_{6} / \mathrm{TMS}\right) \delta_{\mathrm{H}}$ ppm: 6.85-7.85 $(\mathrm{m}, 8 \mathrm{H}, \mathrm{Ar}-\mathrm{H}), 8.45(\mathrm{~s}, 1 \mathrm{H},-\mathrm{N}=\mathrm{CH}), 10.15(\mathrm{~s}, 1 \mathrm{H}, \mathrm{Ar}-\mathrm{OH}), 11.73$ (s, 1H, CO-NH). Anal. Cald. $\mathrm{C}_{15} \mathrm{H}_{11} \mathrm{~F}_{3} \mathrm{~N}_{2} \mathrm{O}_{3}$. Calculated/Found (\%): C: 55.56/54.59 H: 3.42/3.28 N: 8.64/8.26.

N'-\{[4-fluoro-3-(methoxy)phenyl]methylidene\}-4-hydroxybenzohydrazide (3e)

Brown solid. Yield 63\%; m.p. 256-257 ${ }^{\circ} \mathrm{C}$; MW: 288.27 g/mol; Rf: 0.68; Rt value: 1.649 min (M1). FT-IR v max. (cm-1): 3201 (O-H), 3088 (N-H), 3012 (Arom C-H), 2941 (Aliph. C-H), 1651 ( C=O), 1608 (C=N), 1579, 1543, 1496, 1467 (arom. C=C, N-H, C-N), 1236 (C-O), 1107 (C-F). ${ }^{1} \mathrm{H}-\mathrm{NMR}$ (300 MHz, DMSO-d 6 /TMS) $\delta_{\mathrm{H}}$ ppm: 3.91 (s, 3H, O-CH 3$), 6.86-7.83(\mathrm{~m}, 7 \mathrm{H}, \mathrm{Ar}-\mathrm{H}), 8.40(\mathrm{~s}, 1 \mathrm{H},-\mathrm{N}=\mathrm{CH}), 10.14(\mathrm{~s}, 1 \mathrm{H}, \mathrm{Ar}-\mathrm{OH}), 11.68(\mathrm{~s}, 1 \mathrm{H}, \mathrm{CO}-\mathrm{NH})$. Anal. Cald. $\mathrm{C}_{15} \mathrm{H}_{13} \mathrm{FN}_{2} \mathrm{O}_{3}$. Calculated/Found (\%): C: 62.50/61.85 H: 4.55/4.15 N: 9.72/9.77.

$N^{\prime}$-\{[2-chloro-3-(methoxy)phenyl]methylidene\}-4-hydroxybenzohydrazide (3f)

White solid. Yield 70\%; m.p. 270-271 ${ }^{\circ} \mathrm{C}$; MW: 304.72 g/mol; Rf: 0.71; Rt value: 1.769 min (M1). FT-IR v max. (cm-1): $3281(\mathrm{O}-\mathrm{H}), 3047$ (N-H), 3010 (Arom C-H), 2947 (Aliph. C-H), 1645 ( C=O), 1604 (C=N), 1579, 1564, 1506, 1469 (arom. C=C, N-H, C-N), 1232 (C-O), 1105 (C-Cl). ${ }^{1} \mathrm{H}-\mathrm{NMR}$ (300 MHz, DMSO-d 6 /TMS) $\delta_{\mathrm{H}}$ ppm: 3.89 
(s, 3H, O-CH $\mathrm{CH}_{3}$, 6.84-7.84 (m, 7H, Ar-H), 8.86 (s, 1H, -N=CH), 10.18 (s, 1H, Ar-OH), 11.88 (s, 1H, CO-NH). Anal. Cald. $\mathrm{C}_{15} \mathrm{H}_{13} \mathrm{ClN}_{2} \mathrm{O}_{3}$. Calculated/Found (\%): C: 59.12/58.17 H: 4.30/4.06 N: 9.19/9.14.

$N^{\prime}$-\{[3,5-bistrifluoromethylphenyl]methylidene\}-4-hydroxybenzohydrazide (3g)

White solid. Yield 66\%; m.p. $253^{\circ} \mathrm{C}$; MW: 394.26 g/mol; Rf: 0.56; Rt value: $2.892 \mathrm{~min}$ (M1). FT-IR v max. (cm-1): $3242(\mathrm{O}-\mathrm{H}), 3049$ (N-H), 2970 (Arom C-H), 2902 (Aliph. C-H), 1687 (C=O), 1602 (C=N), 1583, 1556, 1512, 1487 (arom. C=C, N-H, C-N), 1238 (C-O), 1111 (C-F). ${ }^{1} \mathrm{H}-\mathrm{NMR}$ (300 MHz, DMSO-d 6 /TMS) $\delta_{\mathrm{H}}$ ppm: 6.86-8.37 $(\mathrm{m}, 7 \mathrm{H}, \mathrm{Ar}-\mathrm{H}), 8.55$ (s, $1 \mathrm{H},-\mathrm{N}=\mathrm{CH}), 10.28(\mathrm{~s}, 1 \mathrm{H}, \mathrm{Ar}-\mathrm{OH}), 12.07$ (s, $1 \mathrm{H}, \mathrm{CO}-\mathrm{NH})$. Anal. Cald. $\mathrm{C}_{16} \mathrm{H}_{10} \mathrm{~F}_{6} \mathrm{~N}_{2} \mathrm{O}_{2}$. $\mathrm{H}_{2} \mathrm{O}$ Calculated/Found (\%): C: 48.74/49.06 H: 3.07/2.87 N: 7.11/6.84.

$N^{\prime}-\{[2,6$-dimethoxyphenyl]methylidene\}-4-hydroxybenzohydrazide (3h)

Grey solid. Yield 55\%; m.p. 211-212 ${ }^{\circ} \mathrm{C}$; MW: 318.32 g/mol; Rf: 0.91; Rt value: 1.566 min (M1). FT-IR v max. (cm-1): 3219 (O-H), 3088 (N-H), 3001 (Arom C-H), 2939 (Aliph. C-H), 1680 (C=O), 1604 (C=N), 1579, 1546, 1510, 1456 (arom. C=C, N-H, C-N), 1253 (C-O). ${ }^{1} \mathrm{H}-\mathrm{NMR}$ (300 MHz, DMSO-d 6 /TMS) $\delta_{\mathrm{H}}$ ppm: 3.80 (s, 6H, O$\left.\mathrm{CH}_{3}\right), 6.73-8.07(\mathrm{~m}, 7 \mathrm{H}, \mathrm{Ar}-\mathrm{H}), 8.56(\mathrm{~s}, 1 \mathrm{H},-\mathrm{N}=\mathrm{CH}), 10.14(\mathrm{~s}, 1 \mathrm{H}, \mathrm{Ar}-\mathrm{OH}), 11.47$ (s, 1H, CO-NH). Anal. Cald. $\mathrm{C}_{16} \mathrm{H}_{16} \mathrm{~N}_{2} \mathrm{O}_{4} . \mathrm{H}_{2} \mathrm{O}$ Calculated/Found (\%): C: 60.37/60.86 H: 5.70/5.80 N: 8.80/8.94.

N'-\{[4-phenylthiophen-2-yl]methylidene\}-4-hydroxybenzohydrazide (3i)

Yellow solid. Yield 80\%; m.p. 290-291 ${ }^{\circ} \mathrm{C}$; MW: 322.38 g/mol; Rf: 0.80; Rt value: 2.259 min (M1). FT-IR v max. (cm-1): 3296 (O-H), 3047 (N-H), 3001 (Arom C-H), 2966 (Aliph. C-H), 1676 (C=O), 1622 (C=N), 1595, 1552, 1506, 1450 (arom. C=C, N-H, C-N),1236 (C-O). ${ }^{1} \mathrm{H}-\mathrm{NMR}$ (300 MHz, DMSO-d 6 /TMS) $\delta_{\mathrm{H}}$ ppm: 6.84-7.98 (m, $11 \mathrm{H}, \mathrm{Ar}-\mathrm{H}), 8.69$ (s, $1 \mathrm{H},-\mathrm{N}=\mathrm{CH}), 10.16(\mathrm{~s}, 1 \mathrm{H}, \mathrm{Ar}-\mathrm{OH}), 11.70$ (s, 1H, CO-NH). Anal. Cald. $\mathrm{C}_{18} \mathrm{H}_{14} \mathrm{~N}_{2} \mathrm{O}_{2} \mathrm{~S}$. Calculated/Found (\%): C: 67.06/66.88 H: 4.38/4.21 N: 8.69/8.73 S: 9.95/10.02.

$N^{\prime}$-\{[4-fluoro-3-(phenoxy)phenyl]methylidene\}-4-hydroxybenzohydrazide (3j)

Grey solid. Yield 66\%; m.p. 205-207 ${ }^{\circ} \mathrm{C}$; MW: 350.43 g/mol; Rf: 0.77; Rt value: 2.425 min (M1). FT-IR v max. (cm-1): 3286 (O-H), $3064(\mathrm{~N}-\mathrm{H}), 3005$ (Arom C-H), 2933 (Aliph. C-H), $1645(\mathrm{C}=\mathrm{O}), 1608$ (C=N), 1575, 1548, 1489, 1456 (arom. C=C, N-H, C-N), 1240 (C-O), 1112 (C-F). ${ }^{1} \mathrm{H}-\mathrm{NMR}$ (300 MHz, DMSO-d 6 /TMS) $\delta_{\mathrm{H}}$ ppm: 6.80$7.81(\mathrm{~m}, 12 \mathrm{H}, \mathrm{Ar}-\mathrm{H}), 8.38(\mathrm{~s}, 1 \mathrm{H},-\mathrm{N}=\mathrm{CH}), 10.15(\mathrm{~s}, 1 \mathrm{H}, \mathrm{Ar}-\mathrm{OH}), 11.69(\mathrm{~s}, 1 \mathrm{H}, \mathrm{CO}-\mathrm{NH})$. Anal. Cald. $\mathrm{C}_{20} \mathrm{H}_{15} \mathrm{FN}_{2} \mathrm{O}_{3}$. Calculated/Found (\%): C: 68.57/67.66 H: 4.32/4.15 N: 8.00/7.51.

\subsection{Anticancer Activity}

\subsubsection{Cell Culture}

Human hepatoma HepG2 cell line was obtained from the American Type Culture Collection (VA, USA). The cells were grown in DMEM supplemented with 10\% FBS and $100 \mathrm{IU} / \mathrm{ml}$ penicillin-streptomycin. The cultures were maintained at $37^{\circ} \mathrm{C}$ in a humidified atmosphere of $5 \% \mathrm{CO}_{2}$.

\subsubsection{MTT Cytotoxicity Assay}

The anticancer activity studies had been performed at Erciyes University, Faculty of Pharmacy, Department of Basic Sciences. The anticancer tests were carried out using the MTT assay. Doxorubicin was used as a positive control reference standard for cell lines. The effect of synthesized molecules (3a-j) on HepG2 cell viability was determined by MTT assay. The MTT assay was based on the principle of the reduction of yellow-colored tetrazolium salt ((3-(4,5-dimethylthiazol-2-yl)-2,5-diphenyltetrazolium bromide) into a purple formazan crystals by the succinate dehydrogenase enzyme in metabolically active cells. Therefore, MTT analysis was used to determine cell viability through the mitochondrial activity of living cells. HepG2 cells were seeded into a 96-well culture dish at a density of 15000 cells/well in $0.1 \mathrm{Ml}$ of DMEM medium. Cells were incubated in a sterile carbon dioxide incubator for 24 hours. After 24 hours, the medium was replaced with fresh medium. Test substances that are thought to affect cell viability were added to the culture medium at various concentrations of compounds (3a-j) $(12.5,25,50,100,200$ and $400 \mu \mathrm{M})$, and the cells were incubated for 24 and 48 hours. At the end of the incubation periods, the medium containing the substances was discarded and $10 \mu \mathrm{l}$ MTT reagent in $100 \mu \mathrm{l}$ medium was added to each well and plates were allowed to incubate for 2 hours. Formazan crystals formed as a result of incubation in viable cells were dissolved in $100 \mu \mathrm{DMSO}$ and absorbance was measured in a microplate reader at a wavelength of $570 \mathrm{~nm}$ [27-28]. 


\subsubsection{Quantitative Real Time Polymerase Chain Reaction}

Expression levels of the Bax, Bcl-2, and caspase-3 genes which were thought to play an important role in apoptosis of the compounds showing anticancer activity in the HepG2 cell line was analyzed by quantitative real-time polymerase chain reaction (qRT-PCR). For this purpose, the cells were seeded in a $100 \times 20 \mathrm{~mm}$ cell culture petri dishes and incubated at $37^{\circ} \mathrm{C}$. When the cell growth reaches $70-80 \%$ fullness in the bottom of petri dish, the medium was replaced with a new medium and the test substances were incubated at the appropriate concentration and 48 hours determined by the MTT test. Total RNA isolation was performed by the manufacturers' protocol, total RNA was purified from cultured cells using trizole RNeasy mini kit (Qiagen Inc., CA, USA). The RNA concentration was measured using a Thermo Scientific NanoDropTM Spectrophotometer (Thermo Fisher Scientific, DA USA). cDNA was synthesized using the Evoscript Universal reverse transcriptase kit (Roche, Switzerland). For qRT-PCR analysis reference and target gene were selected from RealTime Ready Catalog Assays (Roche, Switzerland). qPCR was performed with the LightCycler 480 System (Roche, Switzerland) according to manufacturers protocol to measure the mRNA expression levels of the targeted genes. Pre-incubation at $95^{\circ} \mathrm{C}$ for 10 minutes, 45 repetitions at $95^{\circ} \mathrm{C}$ for 10 seconds, $60{ }^{\circ} \mathrm{C}$ for 30 seconds, $72{ }^{\circ} \mathrm{C}$ for 1 -second annealing cycle and $40^{\circ} \mathrm{C}$ for 30 seconds cooling were recorded on the Real-time PCR instrument. Ct cycle was used to determine the expression level and control and $3 \mathrm{i}$ and $3 \mathrm{j}$ treated cells [29].

\subsubsection{Statistical Analyses}

Data from each group in vitro experiments were evaluated as mean \pm Standard Deviation (SS). Statistical analysis was performed by using the SPSS version 18.0 computer program. Differences between the groups were determined by One-way ANOVA followed by post hoc Dunnett multiple comparison test. A p-value of less than 0.05 was considered statistically significant.

Acknowledgments: The authors acknowledge the financial support of Erciyes University Scientific Research Projects Coordination Unit (THD-2018-8606). In this paper, synthesis and characterization studies are conducted in Marmara University, Faculty of Pharmacy, Pharmaceutical Chemistry Laboratory and thank to Prof Dr. Ş. Güniz KÜÇÜKGÜZEL.

Author contributions: Concept - M.İ.H, Ş.G.K.; Design - M.İ.H, Ş.G.K.; Supervision -Ş.G.K.; Resources - M.İ.H, P.A., N.İ., Ş.G.K.; Materials - M.I.H, P.A., N.İ., Ş.G.K.; Data Collection and/or Processing - M.I.H, P.A., N.İ., Ş.G.K.; Analysis and/or Interpretation - M.İ.H, P.A., N.İ., Ş.G.K.; Literature Search - M.İ.H, P.A., N.İ., Ş.G.K.; Writing - M.İ.H, Ş.G.K.; Critical Reviews - M.İ.H, P.A., N.İ., Ş.G.K.

Conflict of interest statement: The authors declared no conflict of interest.

\section{REFERENCES}

[1] Jonkers N, Sousa, A, Galante-Oliveira, S., Barroso, C.M., Kohler, H.P.E., Giger, W. Occurrence and sources of selected phenolic endocrine disruptors in Ria de Aveiro, Portugal. Environ. Sci Pollut Res. 2017; 17: 834-843. [CrossRef]

[2] Liao X, Raghavan GSV, Yaylayan VA. A novel way to prepare n-butylparaben under microwave irradiation. Tetrahedron Letters. 2002; 43: 45-48. [CrossRef]

[3] Błędzka D, Gromadzińska J, Wąsowicz W. Parabens. From environmental studies to human health. Env Int. 2014; 67: 27-42. [CrossRef]

[4] Elder RL. Final report on the safety assessment of methylparaben, ethylparaben, propylparaben and butylparaben. J A Col Tox. 1984; 3(5): 147-209.

[5] Boberg J, Taxvig C, Christiansen S, Hass U. Possible endocrine disrupting effects of parabens and their metabolites. Rep Tox. 2010; 30: 301-312. [CrossRef]

[6] Smarr MM, Sundaram R, Honda M, Kannan K, Louis GMB. Urinary concentrations of parabens and other antimicrobial chemicals and their association with couples fecundity. Env Heal Persp. 2017; 125: 730-736. [CrossRef]

[7] Rollas S, Küçükgüzel ŞG. Biological Activities of Hydrazone Derivatives. Molecules. 2007; 12: 1910-1939. [CrossRef]

[8] Kömürcü ŞG, Rollas S, Ulgen M, Gorrod JW, Cevikbaş A Evaluation of some arylhydrazones of p-aminobenzoic acid hydrazide as antimicrobial agents and their in-vitro hepatic microsomal metabolism. Boll Chim Farmaceutico. 1995; 134: 375-379. 
[9] Küçükgüzel ŞG, Rollas S, Küçükgüzel İ, Kiraz M. Synthesis and antimycobacterial activity of some coupling products from 4-aminobenzoic acid hydrazones. Eur J Med Chem. 1999; 34: 1093-1100. [CrossRef]

[10] Küçükgüzel ŞG, Mazi A, Sahin F, Öztürk S, Stables J. Synthesis and biological activities of diflunisal hydrazidehydrazones. Eur J Med Chem. 2003; 38: 1005-1013. [CrossRef]

[11] Tatar E, Küçükgüzel İ, Daelemans D, Talele TT, Kaushik-Basu N, De Clercq E, Pannecouque C. Some hydrazones of 2-aroylamino-3-methylbutanohydrazide: synthesis, molecular modeling studies, and identification as stereoselective inhibitors of HIV-1. Arch Pharm Chem Life Sci. 2013; 346: 140-153. [CrossRef]

[12] Tatar E, Şenkardes S, Sellitepe HE, Küçükgüzel ŞG, Karaoglu ŞA, Bozdeveci A, De Clercq E, Pannecouque P, Hadda TB, Küçükgüzel İ. Synthesis, and prediction of molecular properties and antimicrobial activity of some acylhydrazones derived from N -(arylsulfonyl)methionine. Turk J Chem. 2016; 40: 510 - 534. [CrossRef]

[13] Popiołek L, Biernasiuk A. Synthesis and investigation of antimicrobial activities of nitrofurazone analogues containing hydrazide-hydrazone moiety. Saudi Pharm J. 2017; 25: 1097-1102. [CrossRef]

[14] Çıkla P, Tatar E, Kucukguzel İ, Sahin F, Yurdakul D, Basu A, Krishnan R, Nichols DB, Basu NK, Küçükgüzel ŞG. Synthesis and characterization of flurbiprofen hydrazide derivatives as potential anti-HCV, anticancer and antimicrobial agents. Med Chem Res. 2013; 22: 5685-5699. [CrossRef]

[15] Çıkla P, Özsavcı D, Özakpınar ÖB, Şener A, Çevik Ö, Turan SÖ, Akbuga J, Şahin F, Küçükgüzel ŞG. Synthesis, cytotoxicity, and pro-apoptosis activity of etodolac hydrazide derivatives as anticancer agents. Arch Pharm Chem Life Sci. 2013; 346: 367-379. [CrossRef]

[16] Aydın S, Kaushik-Basu N, Arora P, Basu A, Nichols DB, Talele TT, Akkurt M, Çelik İ, Büyükgüngör O, Küçükgüzel ŞG. Microwave assisted synthesis of some novel Flurbiprofen hydrazide-hydrazones as anti-HCV NS5B and anticancer agents. Marmara Pharm J. 2013; 17: 181-189. [CrossRef]

[17] Çıkla P, Küçükgüzel ŞG, Küçükgüzel İ, Rollas S, De Clercq E, Pannecouque C, Andrei G, Snoeck R, Şahin F, Bayrak ÖF. Synthesis and evaluation of antiviral, antitubercular and anticancer activities of some novel thioureas derived from 4-aminobenzohydrazide hydrazones. Marmara Pharm J. 2010; 14: 13-20. [CrossRef]

[18] Küçükgüzel ŞG, Koç D, Süzgün PÇ, Özsavcı D, Özakpınar ÖB, Tiber PM, Orun O, Erzincan P, Erdem SS, Şahin F. Synthesis of tolmetin hydrazide-hydrazones and discovery of a potent apoptosis inducer in colon cancer cells. Arch Pharm Chem Life Sci. 2015; 348: 730-742. [CrossRef]

[19] Şenkardes S, Kaushik-Basu N, Durmaz İ, Manvar D, Basu A, Atalay R, Küçükgüzel ŞG. Synthesis of novel diflunisal hydrazide-hydrazones as anti-hepatitis $\mathrm{C}$ virus agents and hepatocellular carcinoma inhibitors. Eur J Med Chem. 2016; 108: 301-308. [CrossRef]

[20] Keogh A, Senkardes S, Idle JR, Küçükgüzel SG, Beyoglu D. A Novel Anti-Hepatitis C virus and antiproliferative agent alters metabolic networks in HepG2 and Hep3B cells. Metabolites. 2017; 7, 23: 1-16. [CrossRef]

[21] Han Mi, Bekçi H, Cumaoğlu A, Küçükgüzel ŞG. Synthesis and characterization of 1,2,4-triazole containing hydrazide-hydrazones derived from (S)-Naproxen as anticancer agents. Marmara Pharm J. 2018; 22(4): 559-569. [CrossRef]

[22] Han Mİ, Bekçi H, Uba Aİ, Yıldırım Y, Karasulu E, Cumaoğlu A, Karasulu HY, Yelekçi K, Yılmaz Ö, Küçükgüzel ŞG. Synthesis, molecular modeling, in vivo study and anticancer activity of 1,2,4-triazole containing hydrazidehydrazones derived from (S)-naproxen. Arch Pharm Chem Life Sci. 2019; 352 (6): 1-14. [CrossRef]

[23] Kaplancıklı ZA, Yurttaş L, Özdemir A, Turan-Zitouni G, Çiftci GA, Yıldırım SU, Mohsen UA. Synthesis and antiproliferative activity of new 1,5-disubstituted tetrazoles bearing hydrazone moiety. Med Chem Res. 2014; 23: 1067-1075. [CrossRef]

[24] Bhole RP, Bhusari KP. Synthesis, Antihypertensive Activity, and 3D-QSAR Studies of Some New pHydroxybenzohydrazide Derivatives. Arch Pharm Chem Life Sci. 2011; 2: 119-134. [CrossRef]

[25] Akl H, Vervloessem T, Kiviluoto S, Bittremieux M, Parys JB, De Smedt H, Bultynck G. A dual role for the antiapoptotic Bcl-2 protein in cancer: Mitochondria versus endoplasmic reticulum. Biochimica et Biophysica Acta. 2014; 1843: 2240-2252. [CrossRef]

[26] http://www.molinspiration.com

[27] Stockert JC, Blázquez-Castro A, Cañete M, Horobin R W, Villanueva A. MTT assay for cell viability: Intracellular localization of the formazan product is in lipid droplets. Acta Histochemica. 2012; 114(8): 785-796. [CrossRef] 
[28] van Tonder A, Joubert AM, Cromarty AD. Limitations of the 3-(4,5-dimethylthiazol-2-yl)-2,5-diphenyl-2Htetrazolium bromide (MTT) assay when compared to three commonly used cell enumeration assays. BMC Research Notes. 2015; 8(47): 1-10. [CrossRef]

[29] Diao SL, Xu HP, Zhang B, Ma BX, Liu XL. Associations of MMP-2, BAX, and Bcl-2 mRNA and Protein Expressions with Development of Atrial Fibrillation. Medical Science Monitor. 2016; 22: 1497-1507. [CrossRef]

This is an open access article which is publicly available on our journal's website under Institutional Repository at http://dspace.marmara.edu.tr. 